\title{
The Right Strategy for Coastal Zone Development
}

\author{
I Putu Ananda Citra ${ }^{1}$, A Sediyo Adi Nugraha ${ }^{2}$ \\ \{ananda.citra@undiksha.ac.id ${ }^{1}, \underline{\text { adi.nugraha@undiksha.ac.id²\} }}$ \\ Universitas Pendidikan Ganesha, Indonesia ${ }^{12}$
}

\begin{abstract}
The research location was carried out in Pemuteran Village, Buleleng Regency with the aim of (1) analyzing the distribution of potential coastal resources, and (2) formulating a coastal development strategy in Pemuteran Village. This study used a descriptive design. Data were collected using observation techniques related to resource potential, interviews, and documentation to change the information in formulating coastal development strategies. Furthermore, the data were analyzed qualitatively with the SWOT matrix table. The results showed (1) the potential of coastal resources which are grouped into well-known empathy along the coast of Tejakula Village. Biological resources (coral reefs and fish), artificial resources (making pyramid salt), artificial resources (boats, diving equipment rental), and environmental resources (making and installing coral reef / biorock media, diving, and snorkeling activities). (2) The strategy for developing coastal areas in Pemuteran Village which are favored is in the field of fisheries, namely fish farming in the form of ponds/cages because the demand for fish in tourist areas is very high, in the tourism sector that has not yet developed the craft industry for the needs of tourism activities, and in the tourism sector, namely mapping the potential of coral reefs. Coral because it is the main capital in tourism development in Pemuteran Village.
\end{abstract}

Keywords: strategy, potential, coastal resources

\section{Introduction}

The coastal area is the meeting point between land and sea. To the land, the coastal area includes parts of the land, both dry and submerged in water, which is still influenced by marine characteristics such as tides, sea breezes, and saltwater infiltration. Meanwhile, towards the sea, the coastal area includes parts of the sea that are still influenced by natural processes that occur on land such as sedimentation and freshwater flows, as well as those caused by human activities on land such as deforestation and pollution. Indonesia is the largest archipelago country in Asia. As much as $2 / 3$ of the area is ocean. This means that the potential for coastal resources is abundant. This potential is reflected in a large amount of biodiversity, the potential for coastal, marine aquaculture, and marine tourism.

The regency in north Bali with the widest regency category with the longest beach in Bali is Buleleng Regency. The position of Buleleng Regency which is Nyegare-Gunung is located between the hills and the coastal area. Coastal resource potentials such as coral reefs are being developed by one of the villages in Gerokgak District, namely Pemuteran Village. The potential of coral reefs is a trigger or stepping stone to be able to develop coastal areas in Pemuteran Village as a Tourism Village. The importance of identifying other potentials and 
formulating a strategy for their development is an urgent matter to do. This is potential support for coastal communities in Pemuteran Village.

Healthy coral reefs have various positive impacts on coastal ecosystems and benefit coastal communities, especially fishermen. Damage to coral reefs is influenced by upstream areas and poor coastal management. Thus, it is necessary to manage and conserve coral reefs which can affect the abundance of coral fish as well as improve the economy of fishing communities and tourism businesses in coastal areas. Fishermen are the main source of livelihood for the Pemuteran Village community so that strategies are pursued in managing coastal resources that open business opportunities for the wider community. Based on this description, the purpose of this research is to formulate a strategy for developing the coastal area of Pemuteran Village.

\section{Methods}

The design used in this research is descriptive research concerning the research design proposed by [1]. The data were collected using observation techniques related to the potential of coastal resources, interviews with fishermen groups, village heads, and tourism managers, to gather information in formulating strategies for developing coastal areas. Documentation techniques by taking pictures in the field related to the potential of coastal resources to gather information in formulating strategies for developing coastal areas. Furthermore, the potential distribution data is analyzed qualitatively visualized in the form of a map, while the analysis in formulating a strategy for developing coastal areas uses SWOT analysis techniques, in this study refers to the SWOT matrix by [2].

\section{Result and Discussion}

\section{Distribution of Coastal Resources Potential}

Coastal resources in Pemuteran Village are very diverse. Coastal resources are a source of income and livelihood for the community, especially in coastal areas. The importance of coastal resources so that management must be integrated [3]; [4]. There is potential for coastal resources that have or have not been developed by the village. The potential of coastal resources that have been developed and utilized in Pemuteran Village are as follows.

1) Biological resources include coral reefs, catch fish (grouper, snapper, skipjack tuna, anchovies, and other types of reef fish. The average catch is $20 \mathrm{~kg}$ per day.

2) Non-biological resources include sand used for sculpture crafts, salt ponds that produce pyramid salt products with overseas marketing.

3) Artificial Resources include docks for anchoring fishing boats, marine fishery tools such as boats, nets, and fishing rods. An artificial coral reef called biorock is typical coral reef cultivation in Pemuteran Village.

4) Environmental Service Resources include tourism activities in the form of diving and snorkeling to enjoy the beauty of natural and artificial coral reefs (biorock).

There are four types of potential coastal resources in Pemuteran Village. The potential of coastal resources that are owned by the coastal village of Pemuteran, is the basic capital for the development of coastal areas, especially people who are fishermen. As expressed by [5]inequality occurs in coastal communities where the potential is great, but the economic conditions of the community are low. 
Pemuteran Village has complete coastal resource potential. The potential of coastal resources owned by the coastal area of Pemuteran Village is the basic capital and dominant factor for regional development [6];[7]. The development of the coastal area has implications for the Pemuteran Village community, especially those in the coastal area[8]. Apart from being fishermen, the community can be involved in the tourism service sector. Services in the tourism sector such as tour guides, diving equipment rental, and marine transportation to deliver tourists to enjoy the beauty of the sea. This is a strength and opportunity in developing coastal areas. The next discussion is to formulate a strategy for developing coastal areas.

\section{Coastal Resource Management Strategy in Pemuteran Village}

In managing Coastal Resources in Pemuteran Village, the right strategy is needed. Analyzing internal and external factors that are owned by Pemuteran Village, it can be formulated as an alternative strategy in Coastal Resource Management in Pemuteran Village. The alternative strategies in question are as follows.

1) Adding fish and shrimp ponds. The cultivation of grouper and shrimp provides added value to community income related to coastal resources in Pemuteran Village. The technical aspects of cultivation are selecting strategic marine cultivation locations, selecting good seeds, selecting a feed, and observing fish growth, and selecting healthy fish. This is in line with the research conducted by [3] related to the selection of fish, seaweed, and pearl oyster farming locations. Determining the right location, the chances of success for fishermen are higher.

2) Mapping the distribution of coral reefs (spot diving and snorkeling). Mapping the distribution of coral reefs for tourist attraction, so that tourism promotion will be more effective. This is in line with research [9]. In this case, it is a coral reef that is being conserved, the goal is to protect the coral reef ecosystem or marine from damage caused by natural and human factors. Mapping coral reefs based on mature and new species in the nursery process, making it easier for tourists to determine which coral reef destinations to visit.

3) Adding to the salt industry. Addition of salt industry in Pemuteran Village to improve the economy of the community in Pemuteran Village. By using the plot-plot method with greenhouse media in the process of crystallization and evaporation. Good weather is needed in the process of forming the salt. The impact of this industry is expected to increase people's creativity in entrepreneurship and motivate people to innovate.

4) Set up a fish auction place. The availability of fish auction facilities will make it easier for fishermen to sell or market their catch. construction of fish auction places is one of the economic empowerment models for coastal communities proposed by [10]. As well as protecting fishermen in terms of price games that can be played by traders. Technically, by making a license through the competent agency and coordinating the auction or sales procedure.

5) Community empowerment towards industrial activities for tourism needs. Empowering people to be able to become entrepreneurs, in increasing creativity and economy. The importance of the entrepreneurial culture of local communities was also stated by [11] to be able to produce products that could compete with foreign products. This can improve the industry, especially in the fisheries and tourism sector in Pemuteran Village. 
Providing a limitation means processed salt products from outside the region. The making of written regulations by the local government has a big impact on community empowerment.

6) Make a cooperation agreement with the tourism business actor (biorock). The existence of cooperation between the community and the private sector or government can increase the product in large quantities/scale. The technique is to make agreements or MoUs with tourism agencies in maintaining coral reefs.

7) Community empowerment in pond fish farming. Community empowerment has the opportunity to increase community knowledge and insights in terms of pond fish cultivation. Increasing the income of coastal communities, maintaining coastal ecosystems, and managing coastal areas are strategies for developing coastal areas in a sustainable manner [4]. It is hoped that it will be able to provide motivation and increase community creativity.

8) Increase public awareness to protect the coastal environment. The importance of raising public awareness for the creation of a sustainable coastal ecosystem. This is in line with research [12] on the importance of community awareness in responsibly managing the coast. Increasing public awareness in protecting the environment around the coast is very necessary to prevent pollution. The technique is the involvement of the local government in providing socialization about the environment.

9) Community empowerment in the salt industry. Community empowerment has the opportunity to increase community knowledge and insight so that they can be selfemployed. The technique is to provide training and capital to help people obtain raw materials and produce salt. The technique is to provide capital loans to the community through savings and loan cooperatives.

10) Collaborate with hotels and restaurants to use local fish. The existence of cooperation between the community and private or government parties has the potential to maximize community marine products. cooperation between the community and the private sector or the government can increase the product on a large number/scale. The technique is to make an agreement or MoU with the related tourism agency so that business actors in Pemuteran Village use the fish caught by the local community. With this, it is hoped that the community's fish catches can be managed optimally and sustainably so that the welfare of the local community is guaranteed.

11) Enforce awig-awig or the law in protecting the environment. To avoid violation of awigawig in protecting the environment from persons who might exploit coral reefs. This is in line with research [13] which states that the role of awig-awig has a major effect on environmental sustainability. Law enforcement or awig-awig is very important because it protects the community to maintain tourism potential in Pemuteran Village. Technically, by making written regulations and binding sanctions for violators.

12) Making the salt industry a souvenir. Due to the difficulty of marketing the salt due to the price that is too high. So innovation and creativity are needed as well as salt producers to market their products in souvenir packaging. Technically, the limitation for the entry of 
handicraft products from outside the region so that local production is distributed optimally.

\section{Conclusion}

Coastal resources in Pemuteran Village can be grouped into four, including biological resources (coral reefs and capture fisheries), non-biological resources (sand and salt), artificial resources (jetty, biorock, and fishing equipment), environmental service resources (diving and snorkeling). The right strategy in developing coastal areas in Pemuteran Village is in the field of fisheries, namely fish farming in the form of ponds/cages because the demand for fish in tourist areas is very high, in the tourism sector, namely the underdevelopment of the craft industry for the needs of tourism activities, and the tourism sector, namely mapping the potential of coral reefs because as the main capital in tourism development in Pemuteran Village.

\section{References}

[1] H. S. Yunus, Contemporary Area Research Methodology (in Bahasa). Yogyakarta: Pustaka Pelajar, 2010.

[2] F. Rangkuti, SWOT Analysis Technique of Dissecting Business Cases (in Bahasa). Jakarta: PT Gramedia Pustaka Utama, 2004.

[3] U. Utojo, A. Mansyur, A. Mustafa, H. Hasnawi, and A. M. Tangko, "Selection of Environmentally Friendly Fish, Seaweed, and Pearl Oyster Farming Locations in the Togean Island, Central Sulawesi (in Bahasa)," J. Ris. Akuakultur, vol. 2, no. 3, p. 303, 2016.

[4] M. Aris, A. Fahrudin, E. Riani, and E. Muttaqin, "Sustainability Analysis of the Marine Recreational Park (MRP) Management in Weh Island Based on Local Customary Law of the Sea (Hukom Adat Laot) (in Bahasa)," J. Mns. dan Lingkung., vol. 25 , no. 1, p. $25,2020$.

[5] Y. Zebua, P. K. Wildani, A. Lasefa, and Riki Rahmad, "Factors Causing the Low Welfare of Sri Mersing Coastal Fisherman in Kuala Lama Village, Serdang Bedagai District, North Sumatera (in Bahasa)," J. Geogr., vol. 9, no. 1, pp. 88-98, 2017.

[6] Y. F. Wismayanti, "Social Conditions of Child Workers (Assessment of Child Labor in the Coastal Areas of Cumpat and Nambangan, Bulak Banteng, Surabaya City) (in Bahasa)," Sosio konsepsia J. Penelit. DAN Pengemb. Kesejaht. Sos., vol. 11, no. 1, pp. 36-46, 2017.

[7] M. Obie, E. Soetarto, T. Soemarti, and S. Saharuddin, "History of Control of Coastal and Sea Resources in the Tomini Bay (in Bahasa)," Paramita Hist. Stud. J., vol. 25, no. $1,2015$.

[8] S. Sariffudin, P. Purwanti, and H. Riniwati, "Marine Cultivation Development (Mariculture) for Coastal Areas and Small Islands Communities in North Halmahera Regency (in Bahasa)," J. Pembang. dan alam lestari, vol. 2, no. 2, 2013.

[9] N. Khakhim, D. Soedharma, A. Mardiastuti, V. P. Siregar, and M. Boer, "Analysis of the Visual Preferences of the Coastal Landscape of the Special Region of Yogyakarta for the Development of Coastal Tourism towards Sustainable Coastal Zone Management (in Bahasa)," Forum Geogr., vol. 22, no. 1, p. 44, 2008. 
[10] I. G. M. Subagiana, I. G. L. S. Artatanaya, and N. L. M. Wijayati, "Coastal Community Economic Empowerment Model (PEMP) in Three Water Fishing Villages, Pengambengan and Candikusuma, Jembrana Regency, Bali Province (a Comparative Study) (in Bahasa)," J. Bisnis dan Kewirausahaan, vol. 14, no. 2, pp. 92-98, 2018.

[11] I. Chairunnisa, R. Rijanta, and M. Baiquni, "Understanding the Maritime Culture of Depok Beach Community, Bantul Regency (in Bahasa)," Media Komun. Geogr., vol. 20, no. 2, p. 199, 2019.

[12] T. Kusumastanto and M. M. Kamal, "Analysis of Fishermen's Perceptions in Sustainable Fisheries Resources Management in Karimunjawa National Park (in Bahasa)," Tataloka, vol. 13, no. 2, pp. 70-81, 2016.

[13] P. I. Christiawan, "Cultural landscape: A bridge between deforestation and local community?," J. Landsc. Ecol. Republic), vol. 11, no. 1, pp. 77-87, 2018. 